\title{
COST EFFICIENCY OF RETROFIT MEASURES FOR TYPICAL MASONRY HOUSES IN KOSOVO
}

\author{
EGZON BAJRAKTARI ${ }^{1}$, VIOLETA NUSHI ${ }^{1, *}$, MANUELA ALMEIDA $^{2}$ \\ ${ }^{1}$ Faculty of Civil Engineering and Architecture, University of Prishtina “Hasan Prishtina”, Kosovo \\ ${ }^{2}$ Department of Civil Engineering, University of Minho, Portugal \\ *E-mail: violeta.nushi@uni-pr.edu
}

\begin{abstract}
A major challenge our society faces today is the energy consumption of buildings. Building stock is responsible for about $40 \%$ of energy consumption worldwide. The same applies to Kosovo, where a large number of houses are poorly weatherized and inefficient in terms of energy consumption. Most of the energy consumption in the household sector in Kosovo is dedicated to the needs for heating purposes. Furthermore, many of these houses use wood or coal for heating, releasing a lot of gases in the air and so contributing to an increased air pollution both indoors and outdoors. The Faculty of Civil Engineering and Architecture at the University of Prishtina "Hasan Prishtina" aims to address the issue of energy efficiency for these houses. Specifically, in this study we intend to evaluate various retrofit measures applicable in the country for typical masonry houses and identify the cost-efficient solution. This paper reports the initial results of the study and discusses related challenges.
\end{abstract}

Keywords: energy retrofit, cost-efficiency, masonry buildings, Kosovo

\section{Introduction}

The building sector accounts for a large portion of global energy use and greenhouse gas emissions. In Kosovo, similarly to global statistics, the household sector is responsible for about $38 \%$ of the overall energy consumption [1]. Most of this energy consumption in the household sector is dedicated to the needs of heating in housing spaces [2, 3]. First projects applying energy efficiency measures in new and existing buildings have begun countrywide.

On the other hand, the government is working toward completing the legislative framework which supports and encourages energy efficiency in the building sector. Both the works in practice and the drafting of the legislation are based on foreign examples. In this regard, there is a need for local standards and benchmarks to be established in the field of energy efficiency and related retrofit measures. Of course, this should be based on the relevant international standards and guiding documents [4-6].
The Faculty of Civil Engineering and Architecture at the University of Prishtina "Hasan Prishtina" with the project LEMENS (original full title "Levërdia Ekonomike e Masave për Efiçiencë Energjetike në Sanimin e Ndërtesave Ekzistuese”, in English: "Cost efficiency of the measures for energy efficiency in the renovation of existing buildings") aims to address the issue of determination of the cost-efficiency of the measures for energy efficiency renovation of existing buildings. To gain an understanding of the practices and problems in the field we have monitored the implementation of the measures for energy efficiency in a number of existing buildings. For the scope of the problem we examined general statistical data for the existing building stock in Kosovo [8]. This paper focuses on the cost-efficient solution for the renovation of masonry type one-floor single-family houses. The general statistical data [8] show that $86-89 \%$ of the whole existing residential building stock has low thermal insulation walls. The majority of the buildings in this stock are single family houses (230303 units from the statistical data of the 2011 year census [8]).

This is an open-access article distributed under the terms of the Creative Commons Attribution-NonCommercial 4.0 International License (https://creativecommons.org/licenses/by-nc/4.0/), which permits unrestricted use, distribution, and reproduction in any medium for non-commercial purposes, provided the original author and source are credited, a link to the CC License is provided, and changes - if any - are indicated. 


\section{Materials and calculation methods}

The examination of the cost efficiency of energy efficiency renovation measures for existing masonry type one-floor single-family houses buildings is done as follows.

A reference house has been modelled for the case study. It is a single-family house, one floor masonry type of building. According to statistical data [8] this model can be inferred to roughly represent $31 \%$ of the units in the existing building stock in Kosovo. These houses use wood stoves for heating, and there is usually one such stove in the main living room. Water heating is provided by separate electrical boilers in the bathroom. The characteristics of the building envelope for the reference house are shown in Table 1 . The walls consist of masonry blocks with mortar on both sides. The roof is a wooden construction covered with roof tiles and over a concrete slab. The floor is a solid concrete floor. Windows are wooden frame, double pane, single glazed.

Table 1. Building envelope characteristics for the reference house

\begin{tabular}{lccl}
\hline $\begin{array}{l}\text { Building envelope } \\
\text { components }\end{array}$ & $\begin{array}{c}S \\
{\left[\mathrm{~m}^{2}\right]}\end{array}$ & $\begin{array}{c}U \\
{\left[\mathrm{Wm}^{-2} \mathrm{~K}^{-1}\right]}\end{array}$ & Main material \\
\hline Floor & 100 & 0.67 & Concrete \\
Walls & 130 & 0.96 & Masonry units \\
Windows & 12 & 2.70 & Glass \\
Door (entry) & 2 & 1.80 & Wood \\
Roof & 148 & 1.85 & Roof tiles \\
\hline
\end{tabular}

This type of house only for heating purposes consumes about $255 \mathrm{kWhm}^{-2} \mathrm{a}^{-1}$. Walls and the roof represent the major paths in transmission losses (Fig. 1).

Various renovation scenarios have been established. They address only renovation measures for the building envelope (walls, windows, roof). The floor has not been considered in the list, since in the case of existing buildings the renovation of the floor will incur other renovation measures and increase the costs as well as the time. On the other hand, the roof and the enveloping walls as well as windows can be (more or less) renovated without interrupting the household and without incurring extra costs. Renovation scenarios addressing one or more building envelope components are listed in Table 2. They consist of various levels of external thermal insulation with expanded polystyrene (EPS) and various levels of roof insulation with mineral wool (MW), as well as three types of windows (double glazed, double glazed low-e and triple glazed low-e).

For the reference house and for each of the renovation scenarios the primary energy and global costs has been calculated. The primary energy is calculated following a standard procedure $[6,7]$ using a quasi-steady state method. For simplification only the primary energy necessary for heating purposes has been calculated. Global costs are simplified in the form of investment costs and energy costs over a certain period of time.

The weather data has been obtained from local weather stations $[9,10]$ as well as satellite data for global radiation [11].

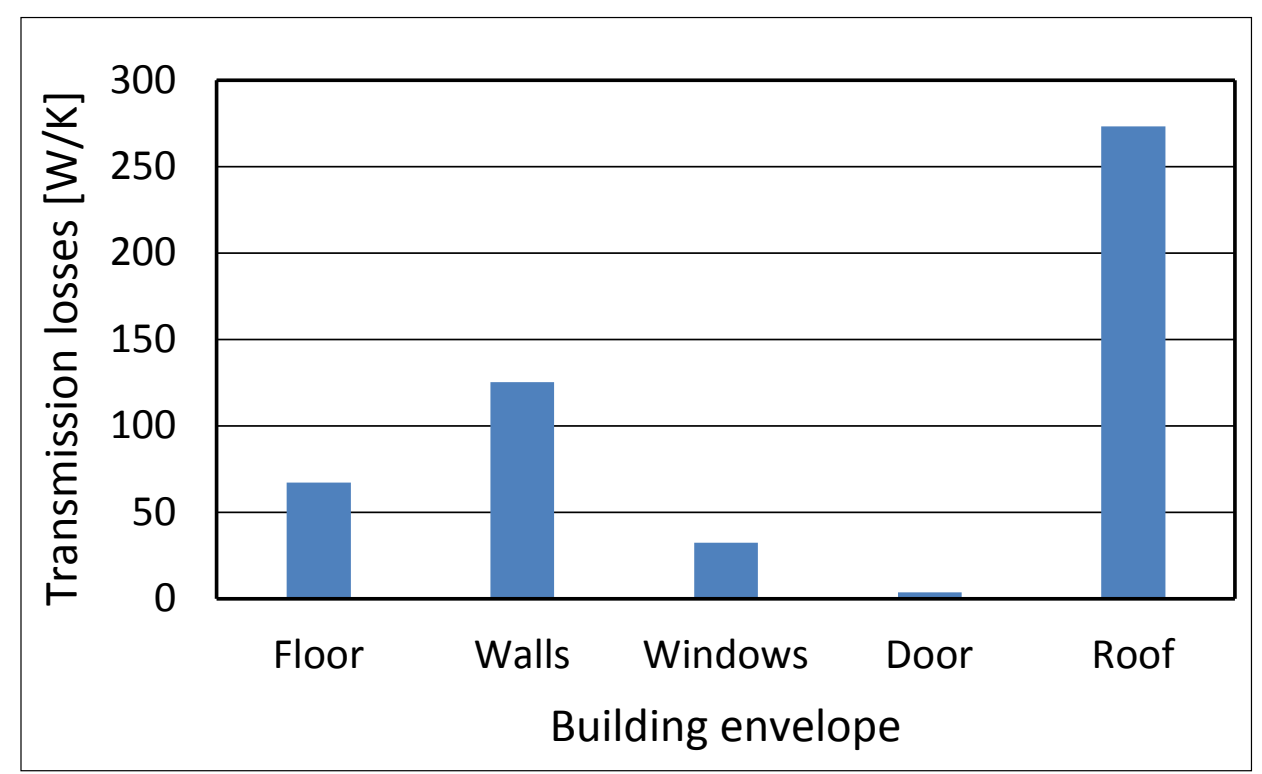

Fig. 1. Transmission losses per building envelope components 
Table 2. List of renovation scenarios

\begin{tabular}{cccl}
\hline Scenario No. & Roof (mm) & Walls (mm) & Windows \\
\hline 1 & MW 50 & - & - \\
2 & - & EPS 50 & - \\
3 & - & - & PVC window Double-glazed U 1.4 \\
4 & MW 50 & EPS 50 & - \\
5 & MW 50 & EPS 50 & PVC window Double-glazed U 1.4 \\
6 & MW 50 & EPS 50 & PVC window Double-glazed Low-e U 1.1 \\
7 & MW 50 & EPS 50 & PVC window Triple-glazed Low-e U 0.8 \\
8 & MW 80 & EPS 50 & PVC window Double-glazed U 1.4 \\
9 & MW 80 & EPS 50 & PVC window Triple-glazed Low-e U 0.8 \\
10 & MW 80 & EPS 80 & PVC window Double-glazed U 1.4 \\
11 & MW 80 & EPS 80 & PVC window Triple-glazed Low-e U 0.8 \\
12 & MW 120 & EPS 50 & PVC window Double-glazed U 1.4 \\
13 & MW 120 & EPS 80 & PVC window Double-glazed U 1.4 \\
14 & MW 120 & EPS 120 & PVC window Double-glazed U 1.4 \\
15 & MW 120 & EPS 80 & PVC window Double-glazed Low-e U 1.1 \\
16 & MW 120 & EPS 120 & PVC window Triple-glazed Low-e U 0.8 \\
17 & MW 150 & EPS 80 & PVC window Double-glazed U 1.4 \\
18 & MW 150 & EPS 120 & PVC window Double-glazed Low-e U 1.1 \\
19 & MW 150 & EPS 150 & PVC window Triple-glazed Low-e U 0.8 \\
20 & MW 250 & EPS 120 & PVC window Triple-glazed Low-e U 0.8 \\
21 & MW 250 & EPS 250 & PVC window Triple-glazed Low-e U 0.8 \\
22 & MW 370 & EPS 370 & PVC window Triple-glazed Low-e U 0.8 \\
\hline & & &
\end{tabular}

\section{Results}

We have calculated the primary energy needs regarding heating purposes for the reference house and for each of the renovation scenarios, as well as related global costs. Figure 2 compares the results for a 30year period, whereas Figure 3 compares the results for a 10-year period.

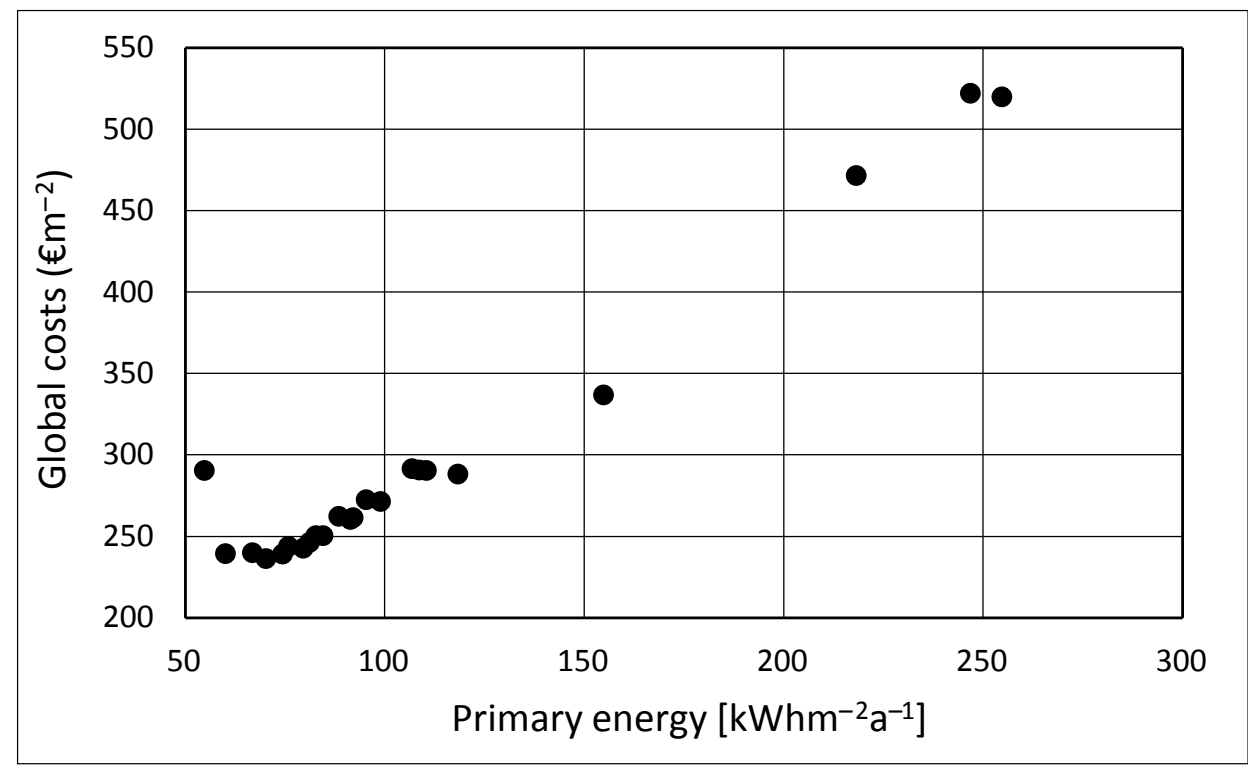

Fig. 2. Comparison of primary energy and global costs for 30 years period 


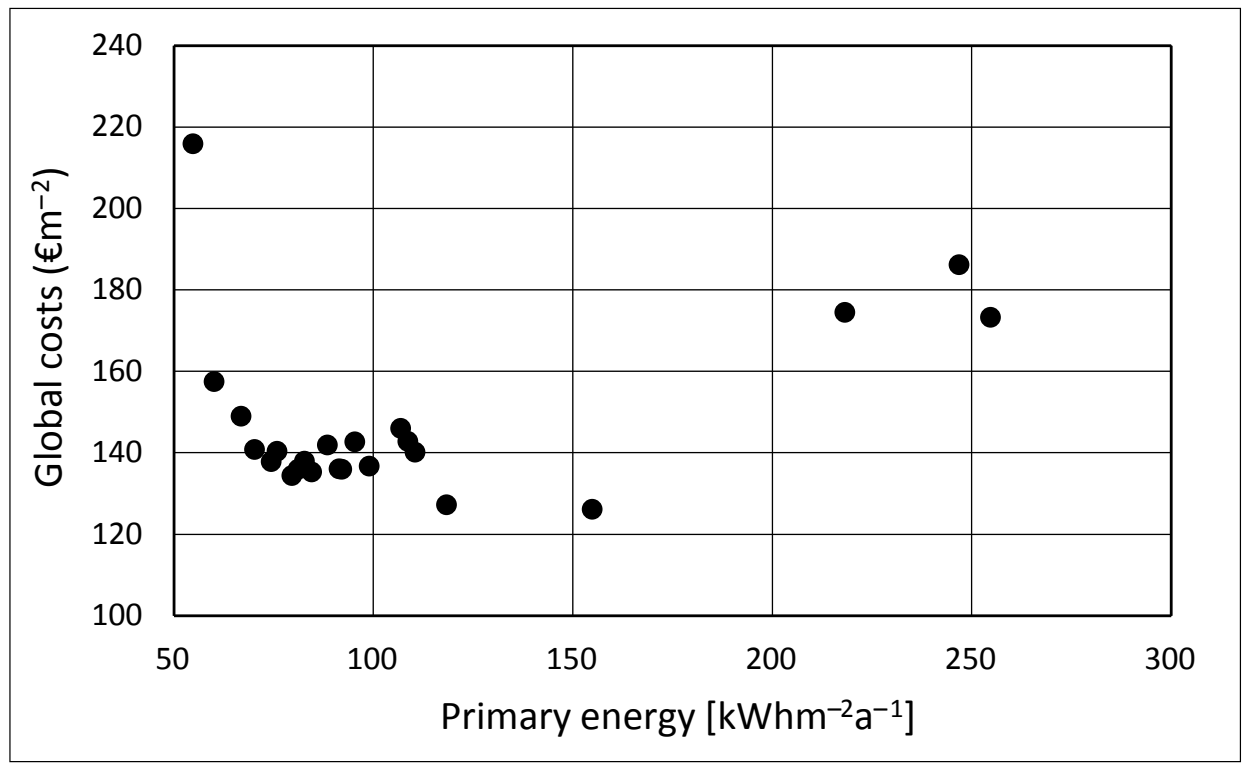

Fig. 3. Comparison of primary energy and global costs for 10 years period

In a 30-year-period scenario 19 (see Table 2 for details) shows to be a cost-optimal solution. Whereas in a shorter period of time scenario 4 and 1 seem more feasible. Calculated figures for each of the data-points including a 20-year calculation period are presented in Table 3.

Table 3. Global costs of the renovation scenarios for 10, 20 and 30 years calculation periods

\begin{tabular}{|c|c|c|c|c|}
\hline \multirow[t]{2}{*}{ Scenario } & \multirow{2}{*}{$\begin{array}{l}\text { Primary energy } \\
\left(\mathrm{kWhm}^{-2} \mathrm{a}^{-1}\right)\end{array}$} & 30-year period & 20-year period & 10 -year period \\
\hline & & \multicolumn{3}{|c|}{ Global costs $\left(€ \mathrm{~m}^{-2}\right)$} \\
\hline Ref. house & 254.8 & 520 & 346 & 173 \\
\hline 1 & 154.9 & 337 & 231 & 126 \\
\hline 2 & 218.3 & 471 & 323 & 174 \\
\hline 3 & 246.9 & 522 & 354 & 186 \\
\hline 4 & 118.4 & 288 & 208 & 127 \\
\hline 5 & 110.5 & 290 & 215 & 140 \\
\hline 6 & 108.7 & 291 & 217 & 143 \\
\hline 7 & 106.9 & 291 & 219 & 146 \\
\hline 8 & 99.0 & 271 & 204 & 137 \\
\hline 9 & 95.4 & 272 & 208 & 143 \\
\hline 10 & 92.2 & 261 & 199 & 136 \\
\hline 11 & 88.5 & 262 & 202 & 142 \\
\hline 12 & 91.4 & 260 & 198 & 136 \\
\hline 13 & 84.6 & 250 & 193 & 135 \\
\hline 14 & 79.6 & 243 & 189 & 134 \\
\hline 15 & 82.7 & 250 & 194 & 138 \\
\hline 16 & 75.9 & 244 & 192 & 140 \\
\hline 17 & 81.2 & 246 & 191 & 136 \\
\hline 18 & 74.4 & 239 & 188 & 138 \\
\hline 19 & 70.2 & 236 & 188 & 141 \\
\hline 20 & 66.8 & 240 & 194 & 149 \\
\hline 21 & 60.2 & 239 & 198 & 157 \\
\hline 22 & 54.8 & 290 & 253 & 216 \\
\hline
\end{tabular}




\section{Discussion}

The results of comparing data over 10-year periods seem to agree with what goes on in practice in current construction works in Kosovo. Considering low economy standing of the local population most of the builders apply very low levels of thermal insulation, meaning short term gain in savings from investments. Nevertheless, on the long run better performing scenario 19 seems the right choice.

In view of the results presented we could recommend that for the current situation in Kosovo it would be possible to require that the existing houses be refurbished using scenario 4 (envelope $U$ value $\sim 0.4$ $\mathrm{Wm}^{-2} \mathrm{~K}^{-1}$ ), while planning that given a better economic standing in the future to advance the refurbishment requirements towards scenario 19 (envelope $U$ value $\sim 0.2 \mathrm{Wm}^{-2} \mathrm{~K}^{-1}$ ). Comparable results have been found in different examples throughout Europe for the single family houses where the $U$ value of the refurbished building envelope has been targeted from 0.16 to 0.3 as seen in [12].

We should note that the better performing renovation scenarios should include also renovation of the heating system, an issue which is not covered in this paper. Single unit wood stoves should be replaced with correctly sized central heating systems in order to avoid overheating in certain spaces and for even distribution of the heat throughout the space.

\section{Conclusion}

Kosovo has a large stock of existing single family houses which are poorly weatherized. It is important that these houses are renovated towards improving their energy efficiency. This study has addressed this issue by examining various retrofit measures for such typical masonry houses. Comparing the primary energy and the global costs in a simplified way this study identifies the cost-optimal solution for the renovation of existing single-family masonry buildings. Considering a 20- to 30-year period for the payback of renovation investments, this study shows it is cost-efficient to target the refurbishment of the building envelope to an average $U$ value of $\sim 0.2 \mathrm{Wm}^{-2} \mathrm{~K}^{-1}$ (scenario 19, Table 3) for the case of existing single family masonry buildings.

\section{Acknowledgements}

This research has been financially supported, in part, by the Ministry of Education, Science and Technology of the Republic of Kosovo (masht.rks-gov.net). Original project title "Levërdia Ekonomike e Masave për Efiçiencë Energjetike në Sanimin e Ndërtesave Ekzistuese", project code LEMENS (prot. no. 1529/2 date 26.04.2017).

\section{References}

[1] MZhE (2013), Balanca Vjetore e Energjise e Republikes se Kosoves per vitin 2014. Ministria e Zhvillimit Ekonomik, Republika e Kosoves. Prishtine, dhjetor 2013 (mzheks.net)

[2] UNDP (2007), Energy for Development - Human Development Report (www.ks.undp.org, last accessed 18.06.2018)

[3] Bowen B. H., Myers J. A., Myderrizi A., Hasaj B., Halili B. (2013), Kosovo Household Energy Consumption Facts and Figures. AUK-RIT Center for Energy and Natural Resources, March 2013, Prishtinë, Kosovo.

[4] The Energy Efficiency Directive 2012/27/EU (“EED”).

[5] EC (2010), Directive 2010/31/EU on the Energy Performance of Buildings. European Commission, L153/13, OJEU, Strasbourg, AT.

[6] ISO. 2017. ISO 52016-1 (2017), Energy performance of buildings - Energy needs for heating and cooling, internal temperatures and sensible and latent heat loads - Part 1: Calculation procedures. (https://www.iso.org/standard/ 65696.html, last accessed 18.06.2018)

[7] IEA (2017), Annex 56. (http://www.iea-annex56.org/, last accessed 18.06.2018)

[8] ASK (2013), Banesat dhe ndertesat sipas komunave. Agjencia e Statistikave e Kosoves, Prishtine, dhjetor 2013 (ask.rks-gov.net)

[9] Instituti Hidrometeorologjik I Kosovws. Vjetari Hidrometeorologjik 2014. MMPH, AMMK, IHK, Shtator 2016 (http://www.ammk-rks.net/repository/docs/Vjetari_ Hidrometeorologjik_-_2014_-_Alb_-_Web_New.pdf, last accessed 18.06.2018)

[10] Degree Days. Custom Degree Day Data (http://www. degreedays.net/, last accessed 18.06.2018)

[11] Global Solar Atlas. World Bank Group. Global Horizontal Radiation Map: Kosovo. (http://globalsolaratlas.info/ downloads/kosovo, last accessed 18.06.2018)

[12] IEA (2017), Shining Examples of Cost-Effective Energy and Carbon Emissions Optimization in Building Renovation (Annex 56) (http://www.iea-annex56.org/) 